Muhammad Ridwan, Isnaini Harahap, Pangeran Harahap: Keputusan Pembelian

\title{
KEPUTUSAN PEMBELIAN MELALUI SITUS BELANJA ONLINE TERHADAP PERILAKU KONSUMTIF MASYARAKAT DALAM PERSPEKTIF EKONOMI ISLAM
}

\section{(Studi kasus Pada Pengguna Aplikasi Lazada di Medan)}

\author{
Muhammad Ridwan*, Isnaini Harahap**, Pangeran Harahap** \\ ${ }^{1}$ Universitas Islam Negeri Sumatera Utara (UINSU) Medan \\ ¿Universitas Islam Negeri Sumatera Utara (UINSU) Medan \\ 3Universitas Islam Negeri Sumatera Utara (UINSU) Medan
}

\begin{abstract}
This study aims to determine the relationship between purchasing decisions, products, prices, services and risks to consumer consumption behavior in Islamic economic perspective The study will observe Lazada Application Users in Medan. The method used is a quantitative approach using multiple linear regression analysis, with statistical tests. The study found that partially there is a relationship of purchase decision to consumptive behavior by 2.013 or $20.13 \%$. Product to consumptive behavior by 2,137 or $21,37 \%$. Price to consumptive behavior by -2.637 or $-26.37 \%$. Service to consumptive behavior by 2,893 or $28,93 \%$. Risk to consumptive behavior by 2.043 or $20.43 \%$. Partially there is a relationship between purchasing decisions, products, prices, services and risks to consumer behavior.
\end{abstract}

Keywords: Purchase Decision, Product, Price, Service, Risk, Consumptive

\section{Abstract}

Penelitian ini bertujuan untuk mengetahui hubungan antara keputusan pembelian, produk, harga, pelayanan, risiko terhadap perilaku konsumtif masyarakat dalam perspektif ekonomi Islam (studi kasus Pada Pengguna Aplikasi Lazada di Medan). Metode yang digunakan yaitu pendekatan kuantitatif dengan menggunakan analisis regresi linier berganda, didukung dengan uji statistik, mengunakan program SPSS versi 20. Pengujian secara parsial koefisien keputusan pembelian terdapat hubungan terhadap perilaku konsumtif sebesar 2,013 atau 20,13\%. Koefisien produk terdapat hubungan terhadap perilaku konsumtif sebesar 2,137 atau $21,37 \%$. Koefisien harga terdapat hubungan terhadap perilaku konsumtif sebesar $-2,637$ atau $-26,37 \%$. Koefisien pelayanan terdapat hubungan terhadap perilaku konsumtif sebesar 2,893 atau $28,93 \%$. Koefisien risiko terdapat hubungan terhadap perilaku konsumtif sebesar 2,043 atau 20,43\%. Secara parsial terdapat hubungan keputusan pembelian, produk, harga, pelayanan dan risiko terhadap perilaku konsumtif.

Kata kunci: Keputusan Pembelian, Produk, Harga, Pelayanan, Risiko, Konsumtif 
j-EBIS Vol. 3 No. 2 Juni 2018

\section{PENDAHULUAN}

Istilah toko online biasa disebut sebagai e-commerce, web store atau virtual store. Dari segi bahasa toko online berasal dari dua suku kata, toko dan online. Menurut kamus bahasa Indonesia, toko berarti sebuah tempat atau bangunan permanen untuk menjual barang-barang (pakaian, makanan, elektronik) dan sebagainya. Sedangkan online adalah sebuah keadaan disaat seseorang terhubung ke dalam sebuah jaringan ataupun sistem yang lebih besar. Dari dua suku kata tersebut dapat ditarik sebuah kesimpulan bahwa toko online adalah tempat terjadinya aktivitas perdagangan atau jual beli barang yang terhubung ke dalam sebuah jaringan, aktivitas itu juga bisa disebut belanja online. Sarwandi (2016)

Setiap manusia yang hidup di atas muka bumi ini selalu berusaha untuk memenuhi kebutuhan hidupnya baik yang bersifat primer maupun sekunder. Islam mengajarkan dalam memenuhi kebutuhan hidup hendaklah kebutuhan (needs) lebih mendominasi bukan sekedar kepada keinginan (wants) hendaknya seorang muslim dalam berbelanja secara adil, dalam arti tidak kurang dan tidak berlebihan dari yang semestinya. Jangan kikir dan boros. Membelanjakan harta untuk kebutuhan pribadi, dianjurkan dengan ukuran kewajaran.

Sebagian masyarakat muslim kota Medan melakukan transaksi berbelanja online untuk membeli barang-barang yang ditawarkan oleh toko online. Transaksi berbelanja online dalam tinjauan fiqih hukumnya adalah mubah selama transaksi yang dilakukan tidak melanggar hukum Islam, barang yang dibeli merupakan barang yang halal terhindar dari perkara yang subhat dan haram, serta tidak terdapat unsur riba, kezaliman dan penipuan. As-Sabatin (2011) Dalam berbelanja online setiap muslim harus memperhatikan bagaimana produk itu digunakan, bukan hanya sebagai pemuas kebutuhan dan keinginan tetapi memahami esensi dari produk tersebut sehingga tidak jatuh kepada perbuatan yang dilarang Allah.

Timbulnya perilaku konsumtif tidak terlepas dari faktor-faktor yang mempengaruhi keputusan seorang konsumen untuk membeli. Menurut Kotler ada beberapa faktor untuk mengambil keputusan dalam membeli yaitu Keputusan tentang jenis produk, bentuk produk, merek, penjualnya, jumlah produk, waktu pembelian, dan keputusan tentang cara pembayaran. Kotler dan Amstrong (1997) Bentuk fisik produk menjadi salah satu pertimbangan konsumen untuk membeli atau tidak. Selain bentuk produk, harga me- 
Muhammad Ridwan, Isnaini Harahap, Pangeran Harahap: Keputusan Pembelian

megang peranan penting dalam pengambilan keputusan untuk membeli. Oleh karena itu, faktor harga dalam pemilihan suatu produk dapat menjadi pertimbangan yang serius dalam mempengaruhi perilaku konsumtif. Pelayanan cepat dan kemudahan transaksi, menjadi salah satu pertimbangan dalam pengembilan keputusan membeli. Pelayanan cepat dan kemudahan transaksi membuat pelanggan senang dan mau untuk membeli produk yang dipasarkan. Seharusnya kaum muslimin saat berbelanja online hanya untuk memenuhi kebutuhan hidupnya saja, namun kini telah terjadi pergeseran dalam aktivitas berbelanja dari memenuhi kebutuhan menjadi keinginan semata tanpa didasari dengan aspek ekonomi Islam.

\section{KAJIAN LITERATUR}

\section{Keputusan Pembelian}

Menurut Schiffman dan Kanuk mendefenisikan keputusan sebagai pemilihan suatu tindakan dari dua pilihan alternatif atau lebih. Seorang konsumen yang hendak memilih harus memiliki pilihan alternatif. Setiadi mendefinisikan bahwa inti dari pengambilan keputusan pembelian adalah proses pengintegrasian yang mengkombinasikan pengetahuan untuk mengevaluasi dua perilaku alternatif atau lebih. Sangadji dan Sopiah (2013).

Dalam melakukan pembelian dari sebelum membeli sampai setelah melakukan pembelian, proses pembelian konsumen melalui tahap-tahap membeli, yang dikonseptualisasikan dalam model lima tahap proses membeli. Model tersebut dapat dilihat di bawah ini:

\section{Gambar. 3}

Model LimaTahap Proses Membeli

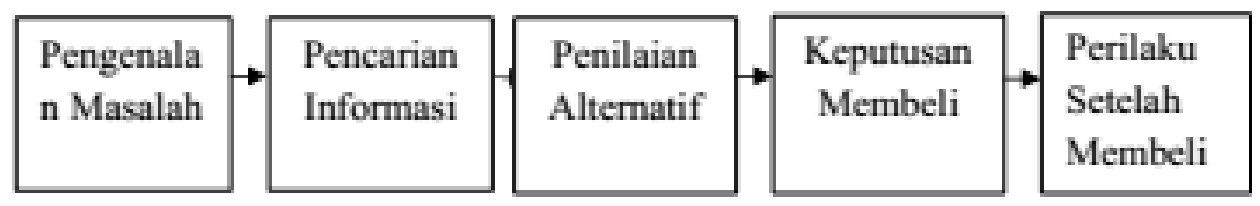

Sumber: Danang Sunyoto (2014)

Seorang muslim pada saat melakukan keputusan pembelian sebuah produk harus mempertimbangkan beberapa hal yaitu barang yang dibeli tidak haram yaitu secara zatnya tidak haram dan cara mendapatkan tidak dengan cara yang haram.

\section{Produk}

Menurut Kamus Besar Bahasa Indonesia produk adalah barang atau jasa yang dibuat 
j-EBIS Vol. 3 No. 2 Juni 2018

dan ditambah guna nilainya dalam proses produksi dan menjadi hasil akhir dari proses produksi. Pusat Bahasa (2008). Produk mencakup lebih dari sekedar barang berwujud (dapat dideteksi pancaindra). Kalau didefinisikan secara luas, produk meliputi objek secara objek secara fisik, pelayanan, orang, tempat, organisasi, gagasan, atau bauran dari semua wujud di atas. Abdullah dan Tantri ( 2012)

Membuat keputusan-keputusan untuk mengelola sebuah produk sering kali bukan hal yang mudah. Ada banyak hal yang harus kita perhatikan kita mulai dengan keputusan tentang manfaat dari produk tersebut. Manfaat produk yang ingin kita tunjukan pada konsumen dapat kita tunjukkan pada konsumen dapat kita komunikasikan dengan atribut-atribut produk diantaranya mutu, fitur, gaya dan desain. Amir (2005)

Produksi merupakan bagian terpenting dari ekonomi Islam dan menjadi titik pangkal dari kegiatan ekonomi. Alquran sebagai pedoman hidup memerintahkan agar manusia melaksanakan kegiatan produksi dengan cara bekerja keras dalam mencari kehidupan, dan mengelola serta mengembangkan alam semesta.

\section{Harga}

Wiliam J. Staton harga adalah jumlah uang (kemungkinan ditambah beberapa barang) yang dibutuhkan untuk memperoleh beberapa kombinasi sebuah produk dan pelayanan yang menyertainya. Laksana (2008).

Strategi untuk menetapkan harga produk sering berubah. Penetapan harga sulit dilakukan karena berbagai produk mempunyai permintaan dan penawaran dan biaya yang dikeluarkan dalam memproduksi dan mendistribusikan produk tersebut, terdapat beberapa strategi penetapan harga yaitu:

a. Keterjangkauan harga

b. Diskon

c. Cara pembayaran. Kotler (1997)

Dalam konsep Islam, yang paling prinsip adalah harga ditentukan oleh keseimbangan permintaan dan penawaran. Keseimbangan ini terjadi bila antara penjual dan pembeli bersikap saling merelakan. Kerelaan ini ditentukan oleh penjual dan pembeli dalam mempertahankan barang tersebut. 
Muhammad Ridwan, Isnaini Harahap, Pangeran Harahap: Keputusan Pembelian

\section{Pelayanan}

Menurut Warren Blanding “ Pelayanan pelanggan merujuk pada aktivitas dari kepuasan pelanggan, dimana pada beberapa kasus berlanjut pada mantenance, atau tehnical support lainya. Pelayanan yang terbaik itulah yang disebut pelayanan prima. Melalui pelayanan prima, perusahaan dapat mempertahankan pelanggan lama. Pelayanan prima dikembangkan berdasarkan konsep A3, yaitu attitude (sikap), attention (perhatian) dan action (tindakan). Subagyo (2010)

Dalam pandangan Islam yang dijadikan tolok ukur untuk menilai kualitas pelayanan terhadap konsumen yaitu standarisasi syariah. Islam mensyariatkan kepada manusia agar selalu terikat dengan hukum syara' dalam menjalankan setiap aktivitas ataupun memecahkan setiap permasalahan.

\section{Risiko}

Risiko adalah terjadinya suatu peristiwa yang menciptakan potensi kerugian dapat bersifat langsung maupun tidak langsung. Kerugian tersebut dapat bersifat finansial dan non finansial. Hardanto ( 2006)

Semakin besar persepsi risiko semakin besar pula kemungkinan keterlibatan konsumen pada pembelian. Ketika persepsi risiko tinggi, konsumen mempunyai pilihan apakah akan menghindari pembelian dan penggunaan atau meminimumkan risiko melalui pencarian dan evaluasi alternatif pra-pembelian dalam tahap pengambilan keputusan. Dimensi-dimensi yang dipersepsikan dari risiko adalah sebagai berikut:

a. Financial Risk

b. Performance Risk

c. Time and Convenience Risk. Yusnidar (2014)

Dalam berbelanja online ada risiko barang rusak dan tidak sesuai dengan keinginan. Sangat jelas bahwa sudut pandang Islam dalam menghadapi risiko mendukung semua upaya untuk mengeliminasi atau memperkecil risiko, sekaligus mempercayai bahwa hanya keputusan Allah lah yang akan menentukan hasilnya.

\section{Perilaku Konsumtif}

Heru Nugroho mengatakan gaya hidup orang yang konsumtif lebih membelanjakan uangnya pada hal-hal yang tidak perlu, pada kebutuhan kebutuhan imajiner. Budiman 
j-EBIS Vol. 3 No. 2 Juni 2018

(2008). Faktor kebudayaan adalah pembentukan yang paling dasar dari keinginan dan perilaku manusia paling banyak adalah belajar. Kelas sosial, kelas sosial adalah divisi masyarakat yang relatif permanen dan teratur dengan para anggotanya menganut nilainilai, minat, dan tingkah laku yang serupa. Kelas sosial bukan ditentukan oleh satu faktor tunggal (pendapatan) tetapi diukur sebagai kombinasi dari pekerjaan, pendapatan, pendidikan, kekayaan, dan variabel lainnya. Ginting (2011)

Dalam ekonomi Islam, konsumsi diakui sebagai salah satu perilaku ekonomi dan kebutuhan asasi dalam kehidupan manusia. Perilaku konsumsi diartikan sebagai setiap perilaku seorang konsumen untuk menggunakan dan memanfaatkan barang dan jasa untuk memenuhi kebutuhan hidupnya. Namun Islam memberikan penekanan bahwa fungsi perilaku konsumsi adalah untuk memenuhi kebutuhan manusia baik jasmani dan ruhani sehingga mampu memaksimalkan fungsi kemanusiaannya sebagai hamba dan khalifah Allah untuk mendapatkan dunia dan akhirat. Harahap dan Ridwan (2016)

\section{METODE PENELITIAN}

Penelitian ini bertujuan melihat hubungan antara variabel independent variabel independen dalam penelitian ini adalah keputusan pembelian $\left(X_{1}\right)$, Produk $\left(X_{2}\right)$, Harga $\left(X_{3}\right)$, Pelayanan $\left(\mathrm{X}_{4}\right)$, Risiko $\left(\mathrm{X}_{5}\right)$. Sedangkan yang menjadi variabel dependennya adalah perilaku konsumtif masyarakat di kota Medan $(Y)$ dengan mengunakan sempel sebanyak 100 orang responden. Adapun teknik/metode pengambilan sampel yang digunakan dalam penelitian ini adalah teknik non probability yakni teknik sampling insidental, yakni teknik penentuan sampel berdasarkan kebetulan, yakni siapa saja yang secara kebetulan/insidental bertemu dengan peneliti dapat digunakan sebagai sampel, bila dipandang orang yang kebetulan ditemui itu cocok sebagai sumber data. Sugiyono (2011)

Jika ditinjau dari tujuannya maka penelitian ini merupakan penelitian hubungan karena menjelaskan hubungan variabel-variabel yang terdapat didalamya, dengan mengunakan kuesioner serta dilakukan pengujian hipotesis yang ajukan.

\section{HASIL DAN PEMBAHASAN}

\section{Analisis Regresi Berganda}

Tujuan dari analisis regresi berganda ini adalah untuk mengetahui dan memprediksi besar pengaruh keputusan pembelian, produk, harga, pelayanan dan risiko terhadap perilaku konsumtif. Berganda dengan menggunakan spss 20 sebagai berikut : 
Tabel. 1

Hasil Pengujian Regresi Berganda

\begin{tabular}{|c|c|c|c|c|c|}
\hline \multirow{3}{*}{$\begin{array}{l}\text { Model } \\
\text { B }\end{array}$} & \multicolumn{5}{|c|}{ Coefficients ${ }^{\mathrm{a}}$} \\
\hline & \multicolumn{2}{|c|}{$\begin{array}{l}\text { Unstandard- } \\
\text { ized Coeffi- } \\
\text { cients }\end{array}$} & \multirow{2}{*}{$\begin{array}{l}\text { Stan- } \\
\text { dard- } \\
\text { i z e d } \\
\text { Coeffi- } \\
\text { cients }\end{array}$} & \multirow[t]{2}{*}{$\mathrm{t}$} & \multirow[t]{2}{*}{ Sig. } \\
\hline & $\begin{array}{l}\text { Std. } \\
\text { E r - } \\
\text { ror }\end{array}$ & Beta & & & \\
\hline (Constant) & & 3.383 & & 2.055 & \\
\hline $\begin{array}{l}\text { Keputusan pembelian } \\
\left(\mathrm{X}_{1}\right)\end{array}$ & .215 & .107 & .196 & 2.013 & \\
\hline $\operatorname{Produk}\left(\mathrm{X}_{2}\right)$ & .231 & .108 & .251 & 2.137 & .035 \\
\hline $\operatorname{Harga}\left(\mathrm{X}_{3}\right)$ & & .099 & -.255 & & .010 \\
\hline Pelayanan $\left(X_{4}\right)$ & .285 & .098 & .296 & 2.893 & \\
\hline Risiko $\left(X_{5}\right)$ & .161 & .079 & .180 & 2.043 & \\
\hline
\end{tabular}

Berdasarkan tabel diatas dapat dibuat persamaan regresi linier berganda sebagai berikut :

$$
\begin{aligned}
& Y=a+b_{1} X_{1}+b_{2} X_{2}-b_{3} X_{3}+b_{4} X_{4}-b_{5} X_{5^{+}} e 1 \\
& Y=6,952+0,215 X_{1}+0,231 X_{2}-0,261 X_{3}+0,285 X_{4}+0,161 X_{5}
\end{aligned}
$$

Dari fungsi model diatas dapat dipahami bahwa :

a. Nilai konstanta 6,952 menyatakan bahwa jika keputusan pembelian, produk, harga, layanan, dan risiko adalah tetap maka perilaku konsumtif meningkat sebesar 6,952.

b. Nilai koefisien keputusan pembelian 0,215 menyatakan jika keputusan pembelian meningkat $1 \%$ maka perilaku konsumtif meningkat 0,215\%. Sebaliknya, jika keputusan pembelian menurun $1 \%$ maka perilaku konsumtif menurun sebesar 0,215\%. Disini keputusan pembelian memiliki pengaruh positif dan signifikan terhadap perilaku konsumtif. Semakin tinggi keputusan pembelian maka perilaku konsumtif akan semakin meningkat. Se- 
j-EBIS Vol. 3 No. 2 Juni 2018

makin baik keputusan pembelian maka akan meningkatkan perilaku konsumtif masarakat di Kota Medan.

C. Nilai koefisien produk menyatakan jika produk meningkat $1 \%$ maka perilaku konsumtif naik 0,231\%. Sebaliknya, jika produk menurun $1 \%$ maka perilaku konsumtif menurun sebesar 0,231\%. Disini produk memiliki pengaruh positif dan signifikan terhadap perilaku konsumtif. Semakin baik produk maka perilaku konsumtif akan semakin meningkat. Semakin baik produk yang ditawarkan kepada konsumen maka akan menurunkan perilaku konsumtif masarakat di Kota Medan.

d. Nilai koefisien harga -0.261 menyatakan jika harga meningkat $1 \%$ maka perilaku konsumtif menurun -0,261\%. Sebaliknya, jika harga menurun 1\% maka perilaku konsumtif naik sebesar 0,446\%. Disini harga memiliki pengaruh negatif dan signifiakn terhadap perilaku konsumtif. Semakin tinggi harga maka perilaku konsumtif akan semakin menurun. Semakin turun harga maka akan meningkatkan perilaku konsumtif masarakat di Kota Medan.

e. Nilai koefisien pelayanan 0.285 menyatakan jika pelayanan meningkat $1 \%$ maka perilaku konsumtif naik sebesar $0,285 \%$. Sebaliknya, jika pelayanan menurun $1 \%$ maka perilaku konsumtif menurun sebesar 0,285\%. Disini pelayanan memiliki pengaruh positif dan signifikan terhadap perilaku konsumtif. Semakin baik pelayanan maka perilaku konsumtif akan menurun. Semakin baik pelayanan maka akan meningkatkan perilaku konsumtif masarakat di Kota Medan.

f. Nilai koefisien risiko 0,161 menyatakan jika risiko meningkat $1 \%$ maka perilaku konsumtif turun sebesar 0,161\%. Sebaliknya, jika risiko menurun $1 \%$ maka perilaku konsumtif naik sebesar 0,161\%. Disini risiko memiliki pengaruh positif dan signifikan terhadap perilaku konsumtif. Semakin tinggi risiko maka perilaku konsumtif akan menurun. Semakin menurun risiko maka akan meningkatkan perilaku konsumtif masarakat di Kota Medan.

\section{Uji Hipotesis}

\section{a. Uji determinasi (R2)}

Uji determinasi (R2) digunakan untuk mengukur sejauh mana kemampuan model dalam menerangkan variasi variabel dependen. Nilai koefisien determinasi adalah di antara nol dan satu. Nilai yang mendekati satu berarti variabel-variabel independen memberikan 
Muhammad Ridwan, Isnaini Harahap, Pangeran Harahap: Keputusan Pembelian

hampir semua informasi yang dibutuhkan untuk memprediksi variasi variabel dependen. Hasil olahan data primer output SPSS 20 mengenai uji determinasi sebagai berikut ini:

Tabel. 2

\section{Uji Koefisien Determinasi (R2)}

Model Summary ${ }^{\mathrm{b}}$
\begin{tabular}{|l|l|l|l|l|}
\hline & $\mathrm{R}$ & $\begin{array}{l}\text { R } \\
\text { Square }\end{array}$ & $\begin{array}{l}\text { Adjusted R } \\
\text { Square }\end{array}$ & $\begin{array}{l}\text { Std. Error } \\
\text { of the Esti- } \\
\text { mate }\end{array}$ \\
\hline 1 & $.564^{\mathrm{a}}$ & .318 & .282 & 2.857 \\
\cline { 2 - 5 }
\end{tabular}

a. Predictors: (Constant), Risiko, Pelayanan, Keputusan_Pembelian, Harga, Produk

b. Dependent Variable: Perilaku_Konsumtif

Sumber Olahan Peneliti 2018

Dari tabel di atas terlihat bahwa pada model regresi linier berganda yaitu : $\mathbf{Y}=\mathbf{a}+\mathbf{b}_{\mathbf{1}} \mathbf{X}_{\mathbf{1}}$ $+\mathbf{b}_{2} \mathbf{X}_{2}-\mathbf{b}_{3} \mathbf{X}_{3}+\mathbf{b}_{4} \mathbf{X}_{4}+\mathbf{b}_{5} \mathbf{X}_{5+}$ e1 menunjukkan nilai koefisien determinasi sebesar 0,318 yang memiliki arti bahwa kontribusi variabel keputusan pembelian, produk, harga, layanan dan risiko terhadap perilaku konsumtif konsumen muslim di Kota Medan adalah sebesar $31,8 \%$ sedangkan sisanya $68,2 \%$ dijelaskan oleh pengaruh faktor-faktor lain.

\section{b. Uji F statistik}

Uji F statistik pada dasarnya menunjukan apakah semua variabel independen yang dimasukan dalam model mempunyai pengaruh secara simultan terhadap variabel dependen. Dari hasil olahan data primer output SPSS 20 mengenai uji F-Statistik sebagai berikut ini:

Tabel. 3

Uji F-Statistik

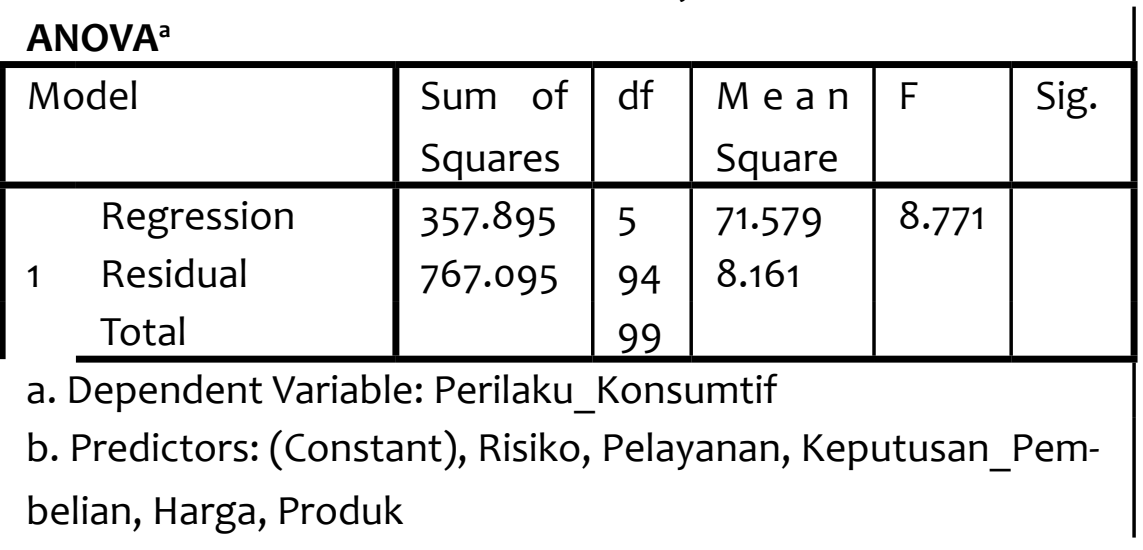

Sumber Olahan Peneliti 2018 
j-EBIS Vol. 3 No. 2 Juni 2018

Berdasarkan hasil pengujian di atas dapat dilihat nilai F-hitung adalah 8,771 dengan nilai signifikansi adalah 0,000000. Nilai F-tabel untuk jumlah obeservasi sebanyak 100 dengan tingkat alpha $5 \%$ dan $\mathrm{k}$ atau jumlah seluruh variabel baik variabel independen dan dependen adalah 4, maka nilai $\mathrm{N}_{1}=\mathrm{k}-1=4-1=3, \mathrm{~N}_{2}=\mathrm{n}-\mathrm{k}=100-4=96$ adalah 2,31. Sehingga diperoleh bahwa F-hitung lebih besardari F-tabel atau 8.771 > 2,31 dan juga dapat dilihat pada nilai probabilitas lebih kecil dari tingkat signifikansi (a) 5\% atau 0,000000 $<0,05$ maka dapat diambil kesimpulan bahwa variabel keputusan pembelian, produk, harga, pelayanan dan risiko secara simultan (bersama-sama) memiliki hubungan terhadap perilaku konsumtif konsumen muslim di Kota Medan dengan kesimpulan $\mathrm{H}_{\mathrm{o}}$ ditolak.

\section{c. Uji t Statistik}

Uji t statistik menunjukan seberapa jauh pengaruh pengaruh satu variabel independen secara parsial dalam menerangkan variasi variabel dependen. Dari hasil olahan data primer output spss 20 mengenai uji t-Statistik sebagai berikut ini :

\section{Tabel. 4}

\section{Uji t-Statistik}

\section{Coefficients $^{\mathrm{a}}$}

\begin{tabular}{|c|c|c|c|c|c|}
\hline \multirow[t]{2}{*}{$\begin{array}{l}\text { Model } \\
\text { B }\end{array}$} & \multicolumn{2}{|c|}{$\begin{array}{l}\text { Unstandard- } \\
\text { ized Coeffi- } \\
\text { cients }\end{array}$} & \multirow{2}{*}{$\begin{array}{l}\text { Sta n - } \\
\text { d a r d- } \\
\text { i z e d } \\
\text { Coeffi- } \\
\text { cients }\end{array}$} & \multirow[t]{2}{*}{$\mathrm{t}$} & \multirow[t]{2}{*}{ Sig. } \\
\hline & $\begin{array}{l}\text { Std. } \\
\text { E r - } \\
\text { ror }\end{array}$ & Beta & & & \\
\hline (Constant) & & 3.383 & & 2.055 & \\
\hline Keputusan pembela $\left(\mathrm{X}_{1}\right)$ & .215 & .107 & .196 & 2.013 & \\
\hline $\operatorname{Produk}\left(X_{2}\right)$ & .231 & .108 & .251 & 2.137 & .035 \\
\hline $\operatorname{Harga}\left(X_{3}\right)$ & & .099 & -.255 & & .010 \\
\hline Pelayanan $\left(\mathrm{X}_{4}\right)$ & .285 & .098 & .296 & 2.893 & \\
\hline Risiko $\left(X_{5}\right)$ & .161 & .079 & .180 & 2.043 & \\
\hline
\end{tabular}

Sumber Olahan Peneliti 2018

Uji t untuk menguji signifikansi setiap variabel independen, yaitu label halal dan brand 
Muhammad Ridwan, Isnaini Harahap, Pangeran Harahap: Keputusan Pembelian

secara parsial (individual) terhadap harga. Dalam hal ini, dasar pengambilan keputusan adalah dengan membandingkan t-tabel dengan thitung. Data di atas diketahui dk (derajat kebebasan) $=100-4=96$ maka $t$-tabel sebesar 1,664. Pedoman yang digunakan untuk menerima atau menolak hipotesis yaitu:

1) Ha diterima jika t-hitung > t-tabel atau prob-value pada kolom sig.<level of significant $(\boldsymbol{\alpha}) \mathbf{5 \%}$ berarti variabel independen memiliki hubungan terhadap variabel dependen.

2) Ho diterima jika t-hitung < t-tabel atau atau prob-value pada kolom sig>level of significant ( $\boldsymbol{\alpha}) \mathbf{5 \%}$ pada kolom berarti variabel independen tidak memiliki hubungan terhadap variabel dependen.

Berdasarkan hasil estimasi pada tabel sebelumnya maka berikut ini hasil uji t statistik dari masing-masing variabel independen sebagai berikut:

1) Keputusan pembelian hasil pengujian dengan menggunakan program SPSS 20 diperoleh nilai t statistik untuk keputusan pembelian adalah 2,013. Sedangkan nilai $t$ tabel untuk jumlah observasi sebanyak 100 dengan derajat kebebasan $(\mathrm{dk})=100-4=96$ diperoleh 1,664. Sehingga diperoleh bahwa t-statistik lebih besar dari t-tabel atau 2,013 >1,664 dan nilai probability sebesar 0,047 lebih kecil dari taraf nyata sebesar 0,05 , maka $\mathrm{H}_{\mathrm{o}}$ ditolak maka dapat diambil kesimpulan bahwa keputusan pembelian secara signifikan mempunyai hubungan terhadap perilaku konsumtif dengan kesimpulan $\mathrm{H}_{\mathrm{o}}$ ditolak dan menerima $\mathrm{Ha}$. Hal ini menyatakan bahwa keputusan pembelian memberikan hubungan nyata terhadap perilaku konsumtif

2) Produk hasil pengujian dengan menggunakan program SPSS 20 diperoleh nilai t statistik untuk produk adalah 2,137. Sedangkan nilai t tabel untuk jumlah observasi sebanyak 100 dengan derajat kebebasan $(\mathrm{dk})=100-4=96 \mathrm{di}-$ peroleh 1,664. Sehingga diperoleh bahwa t-statistik lebih besar dari t-tabel atau $2.137>1,664$ dan nilai probability sebesar sebesar 0,035 lebih kecil dari taraf nyata sebesar 0,05, maka dapat diambil kesimpulan bahwa produk secara signifikan mempunyai hubungan terhadap perilaku konsumtif dengan kesimpulan $\mathrm{H}_{\mathrm{o}}$ ditolak dan menerima $\mathrm{Ha}$. Hal ini menyatakan bahwa produk memberikan hubungan nyata terhadap perilaku konsumtif.

3) Hasil pengujian dengan harga dengan menggunakan program SPSS 20 diperoleh nilai t statistik untuk keputusan pembelian adalah -2.637. Sedangkan 
j-EBIS Vol. 3 No. 2 Juni 2018

nilai t tabel untuk jumlah observasi sebanyak 100 dengan derajat kebebasan $(\mathrm{dk})=100-4=96$ diperoleh 1,664. Sehingga diperoleh bahwa t-statistik lebih besar dari t-tabel sebesar $-2.637<1,664$ dan nilai probability sebesar 0,010 lebih kecil dari taraf nyata sebesar 0,05, maka dapat diambil kesimpulan bahwa harga secara signifikan mempunyai hubungan terhadap perilaku konsumtif dengan kesimpulan $\mathrm{H}_{\mathrm{o}}$ ditolak dan menerima $\mathrm{Ha}$. Hal ini menyatakan bahwa harga memberikan hubungan nyata terhadap perilaku konsumtif.

4) Layanan Hasil pengujian dengan menggunakan program SPSS 20 diperoleh nilai t statistik untuk layanan adalah 2.893. Sedangkan nilai t tabel untuk jumlah observasi sebanyak 100 dengan derajat kebebasan $(\mathrm{dk})=100-4=96 \mathrm{di}$ peroleh 1,664. Sehingga diperoleh bahwa t-statistik lebih besar dari t-tabel atau 2.893>1,664 dan nilai probability sebesar 0,005 lebih kecil dari taraf nyata sebesar 0,05 maka dapat diambil kesimpulan bahwa keputusan pembelian secara signifikan mempengaruhi layanan dengan kesimpulan $\mathrm{H}_{0}$ ditolak dan menerima Ha. Hal ini menyatakan bahwa layanan memberikan pengaruh nyata terhadap perilaku konsumtif

5) Hasil pengujian dengan menggunakan program SPSS 20 diperoleh nilai $t$ statistik untuk risiko adalah 1,821. Sedangkan nilai t tabel untuk jumlah observasi sebanyak 100 dengan derajat kebebasan $(\mathrm{dk})=100-4=96$ diperoleh 1,664. Sehingga diperoleh bahwa t-statistik lebih besar dari t-tabel atau 2,043> 1,664 dan nilai probability sebesar 0,044 lebih kecil dari taraf nyata sebesar 0,05 maka dapat diambil kesimpulan bahwa risiko secara signifikan mempengaruhi keputusan pembelian dengan kesimpulan $\mathrm{H}_{\mathrm{o}}$ ditolak dan menerima Ha. Hal ini menyatakan bahwa risiko memberikan pengaruh nyata terhadap perilaku konsumtif

\section{PEMBAHASAN}

Hipotesis yang diajukan dalam penelitian ini adalah "Apakah terdapat hubungan variabel keputusan pembelian, produk, harga, pelayanan dan risiko terhadap perilaku konsumtif masyarakat Kota Medan”. Berdasarkan hasil penelitian yang diperoleh ialah bahwa, keputusan pembelian, produk, harga, pelayanan dan risiko secara simultan berhubungan terhadap perilaku konsumtif. Hal ini dibuktikan dengan nilai F hitung $8.771>2,31$. Sedangkan secara parsial adalah sebagai berikut: 
Muhammad Ridwan, Isnaini Harahap, Pangeran Harahap: Keputusan Pembelian

1. Hubungan Keputusan Pembelian Mempengaruhi Perilaku Konsumtif Masyarakat Kota Medan

Berdasarkan hasil penelitian variabel keputusan pembelian koefisien regresi sebesar 2,013 > 1,664 dengan tingkat signifikansi sebesar 0,043. Nilai signifikansi tersebut lebih kecil dari 0,05 berarti terdapat hubungan secara signifikan antara variabel keputusan pembelian terhadap perilaku konsumtif maka dapat diambil kesimpulan bahwa keputusan pembelian mempunyai hubungan terhadap perilaku konsumtif. Hal ini menyatakan bahwa keputusan pembelian memberikan hubungan nyata terhadap perilaku konsumtif.

\section{Hubungan Produk Mempengaruhi Perilaku Konsumtif Masyarakat Kota Medan} Berdasarkan hasil penelitian variabel produk koefisien regresi sebesar 2,137 > 1,664 dengan tingkat signifikansi sebesar 0,035. Nilai signifikansi tersebut lebih kecil dari 0,05 berarti terdapat hubungan signifikan antara variabel produk terhadap perilaku konsumtif maka dapat diambil kesimpulan bahwa produk secara signifikan memiliki hubungan terhadap perilaku konsumtif. Hal ini menyatakan bahwa produk memberikan pengaruh nyata terhadap perilaku konsumtif.

\section{Hubungan Harga Mempengaruhi Perilaku Konsumtif Masyarakat Kota Medan}

Berdasarkan hasil penelitian terdapat variabel harga koefisien --2.637> 1,664 dengan tingkat signifikansi sebesar 0,010. Nilai signifikansi tersebut lebih kecil dari 0,05 maka dapat diambil kesimpulan bahwa harga memiliki hubungan terhadap perilaku konsumtif dengan ini menyatakan bahwa harga memberikan hubungan nyata terhadap perilaku konsumtif. Hal ini didukung oleh penelitian yang dilakukan oleh Susanti Wahyuningsih diketahui bahwa harga memberikan pengaruh $28,5 \%$ terhadap perilaku konsumsi.

\section{Hubungan Layanan Mempengaruhi Perilaku Konsumtif Masyarakat Kota Medan}

Berdasarkan hasil penelitian terdapat variabel layanan pembelian koefisien regresi sebesar 2.893>1,664 dengan tingkat signifikansi sebesar 0,005. Nilai signifikansi tersebut lebih kecil dari 0,05 maka dapat diambil kesimpulan bahwa layanan mempunyai hubungan terhadap perilaku konsumtif. Hal ini menyatakan bahwa Setelah mendapatkan pelayanan yang baik dari situs belanja online Lazada seperti ketepatan waktu pengiriman, kesesuaian produk yang didapatkan dengan keterangan yang ada di web, konsumen akan menanamkan rasa kepercayaan pelayanan memberikan pengaruh nyata terhadap perilaku konsumtif. 
j-EBIS Vol. 3 No. 2 Juni 2018

\section{Hubungan Risiko Mempengaruhi Perilaku Konsumtif Masyarakat Kota Medan}

Berdasarkan hasil penelitian variabel risiko koefisien regresi sebesar 2.043>1,664 maka dengan tingkat signifikansi sebesar 0,044. Nilai signifikansi tersebut lebih kecil dari 0,05 dapat diambil kesimpulan bahwa risiko mempunyai hubungan terhadap perilaku konsumtif. Hal ini menyatakan bahwa risiko memberikan pengaruh nyata terhadap perilaku konsumtif.

\section{Kesimpulan}

1. Berdasarkan hasil analisis data yang telah dikemukakan sebelumnya, dapat diambil kesimpulan bahwa hasil analisis regresi linier berganda menunjukkan bahwa secara simultan, keputusan pembelian, produk, harga, pelayanan dan resiko secara simultan berhubungan terhadap perilaku konsumtif. Hal ini dibuktikan dengan nilai $F$ hitung 8.771 > 2,31. Maka kelima variabel berhubungan terhadap perilaku konsumtif masyarakat Kota Medan dapat dijelaskan sebagai berikut:

a. Kofiesien keputusan pembelian $\left(X_{1}\right)$ secara varsial berhubungan terhadap perilaku konsumtif masyarakat kota Medan. Karena t hitung sebesar 2,013 lebih besar dari t tabel 1,664 dan nilai probabilityi sebesar 0,047 lebih kecil dari taraf nyata 0,05. Artinya terdapat hubungan antara keputusan pembelian dengan perilaku konsumtif. Serta dalam melakukan keputusan pembelian konsumen lebih didominasi oleh dorongan pemenuhan rasa kepuasan untuk membeli (wants) dan menghiraukan konsep kebutuhan (needs) dalam persfektif Islam. Hal ini mendorong konsumen berperilaku konsumtif yang lebih mengarah kepada perilaku boros (mubazir).

b. Kofisien produk $\left(\mathrm{X}_{2}\right)$ secara varsial berhubungan terhadap perilaku konsumtif masyarakat kota Medan. Karena t hitung sebesar 2.137 lebih besar dari t tabel 1,664 dan nilai probabilityi sebesar 0,035 lebih kecil dari taraf nyata 0,05. Artinya terdapat hubungan antara produk dengan perilaku konsumtif. Produk yang ditawarkan juga memiliki kejelasan barang dan bentuk, tidak rusak, sesuai dengan kualitas, dan dapat dipastikan kehalalan atau keharamannya.

c. Koefisien harga (X3) secara varsial berhubungan terhadap perilaku konsumtif masyarakat kota Medan. Karena t hitung sebesar -2.637 lebih besar dari t tabel 1,664 dan nilai probabilityi sebesar 0,010 lebih kecil dari taraf nyata 0,05. Artinya terdapat hubungan antara harga dengan perilaku konsumtif. Apabila harga semakin rendah maka penawaran akan semakin banyak dan sebaliknya. Di dalam ekonomi Islam tidak ada yang berhak untuk mengatur tentang 
Muhammad Ridwan, Isnaini Harahap, Pangeran Harahap: Keputusan Pembelian

harga karena di dalam Islam dilarang melakukan praktek monopoli dan mempermainkan harga. Harga ditentukan oleh pasar, membiarkan harga berlaku menurut alamiyahnya tanpa campur tangan dari pihak manapun.

d. Koefisein layanan $\left(\mathrm{X}_{4}\right)$, secara varsial berhubungan terhadap perilaku konsumtif masyarakat kota Medan. Karena t hitung sebesar 2.893 lebih besar dari t tabel 1,664 dan nilai probabilityi sebesar 0,005 lebih kecil dari taraf nyata 0,05. Artinya terdapat hubungan antara layanan dengan perilaku konsumtif. Adanya layanan bayar di tempat serta cepat tanggap dalam menangani masalah pesanan semakin menjauhkan adanya unsur-unsur penipuan dan merugikan orang lain serta memberikan apa yang sudah dijanjikan dengan akurat dan terpercaya.

e. Koefiesien risiko $\left(X_{5}\right)$ secara varsial berhubungan terhadap perilaku konsumtif masyarakat kota Medan. Karena t hitung sebesar 2.043 lebih besar dari t tabel 1,664 dan nilai probabilityi sebesar 0,044 lebih kecil dari taraf nyata 0,05. Artinya terdapat hubungan antara risiko dengan perilaku konsumtif. Semakin tinggi risiko yang diberikan oleh produk maka akan menurun tingkat perilaku konsumtif sebaliknya jika risiko semakin kecil akan menigkatkan perilaku konsumtif. Ekonomi Islam berasal dari Alquran dan Hadis mengarahkan pengikutnya untuk mengihdari risiko yang dapat merugikan diri pribadi.

2. Perilaku konsumsi masyarakat kota Medan mengarah pada perilaku mubazir disebabkan lebih mementingkan keinginan dari pada kebutuhan. Sifat mubazir dapat mengarah pada perbuatan yang dilarang oleh Agama.

\section{SARAN}

Berdasarkan hasil analisis yang telah dilakukan dan adanya keterbatasan dalam penelitian ini, maka peneliti memberikan beberapa saran yaitu:

1. Hasil penelitian ini diharapkan dapat digunakan untuk pengembangan Ekonomi Islam khususnya yang berkaitan dengan keputusan pembelian dan konsumsi masyarakat kota Medan.

2. Sebagai bahan rujukan bagi para peneliti yang ingin memperdalam penelitian tentang perilaku konsumtif dalam perspektif ekonomi Islam. 
j-EBIS Vol. 3 No. 2 Juni 2018

DAFTAR PUSTAKA

Abdullah, Thamrin dan Francis Tantri. 2012. Manajemen Pemasaran. Jakarta: Raja Grafindo Persada.

Amir, Taufiq. 2005. Dinamika Pemasaran: Jelajahi dan Rasakan. Jakarta: RajaGrafindo Persada.

As-Sabatin, Yusuf. 2011. Bisnis Islami dan Kritik Terhadap Bisnis ala Kapitalis terj, Yahya Abdurrahman. Bogor: Al-Azhar Press.

Budiman, Arief, Heru Nugroho, dkk. 2008. Reformasi Politik, Kebangkitan Agama dan Konsumerisme. Yogyakarta: Interfidei.

Ginting, Hartimbul. 2011. Manajemen Pemasaran. Bandung: Yrama Widya.

Harahap, Isnaini dan M.Ridwan. 2006. Islamic Economic. Medan: FEBI Press.

Hardanto, Sulad Sri. 2006. Manajemen Risiko Bagi Bank Umum. Jakarta: Alex Media Komputindo.

Kotler, Philip dan Gary Amstrong. 1997. Prinsip-prinsip Pemasaran Jilid I. Jakarta: PT. Salemba Empat.

Laksana, Fajar. 2008. Manajemen Pemasaran; Pendekatan Prakts. Yogyakarta: Graha Ilmu.

Pusat Bahasa Dapartemen Pendidikan Nasional. 2008. Kamus Besar Bahasa Indonesia. Jakarta: Balai Pustaka.

Sangadji, Etta Mamang dan Sopiah. 2013. Perilaku Konsumen. Yogyakarta : Andi Offset.

Sarwandi. 2016. Toko Online Modern dengan Opencart. Jakarta: Alex Media Komputindo.

Subagyo, Ahmad. 2010. Marketing in Business. Jakarta: Mitra wacana Media.

Sugiyono. 2011. Statistik Untuk Penelitian. Bandung : CV Alfabeta.

Sunyoto, Danang. 2014. Konsep Dasar Riset Pemasaran \& Perilaku Konsumen. Yogyakarta: CAPS.

Yusnidar, Samsir dan Sri Restuti. 2014 . Pengaruh Kepercayaan dan Persepsi Risiko Terhadap Minat Beli dan Keputusan Pembelian Produk Fashion Secara Online di Kota Pekanbaru dalam Jurnal Sosial Ekonomi Pembangunan. vol. 12 No. 4, 2014, hlm. 319-320. 